\title{
An Examination of Students' Views about an International Math Contest
}

\author{
Duygu Ozdemir ${ }^{1 *}$ (1) \\ ${ }^{1}$ Istanbul Aydın University, TURKEY \\ *Corresponding Author: duyguozdemir5@aydin.edu.tr
}

Citation: Ozdemir, D. (2022). An Examination of Students' Views about an International Math Contest. International Electronic Journal of Mathematics Education, 17(2), em0680. https://doi.org/10.29333/iejme/11817

\section{ARTICLE INFO}

Received: 23 Aug. 2021

Accepted: 31 Oct. 2021

\begin{abstract}
Nowadays, mathematics education providing challenging, interesting, interactive and technology-oriented learning experiences to students attracts attention both in research and practice. Among those experiences, competitions, due to their role of integrating the interest and desire of students to compete in education, challenging their potentials and facilitating their adaptation to daily life, are notable issues. In that sense, in the present study, it was aimed to explore the contest-related views of the students participating in a worldwide online mathematics competition and examine these experiences from the gifted education perspective. Based on this aim, 597 third to eleventh-grade students who took part in this international mathematics contest held in 20182019 educational year from 28 different countries constituted the participants of the study. Students' ideas regarding their contest-related experiences were evaluated and then these ideas were examined on whether the contest serves the purpose of students needing extra materials/studies in mathematics, like gifted ones. Findings reflected that $15.7 \%$ of the students' views about such an international, digital math contest are unfavorable while $63.5 \%$ of them are favorable as well as $20.8 \%$ of them indicate their suggestions. Many of the students mentioned that they liked the challenge in the contest, thanked and found it as fun or awesome. It was seen that the contest mostly serves the students who request and desire challenge in their tasks. It was also concluded that the contest can attain the goals of mathematically gifted students searching for extra services in mathematics by providing them challenging problem-solving tasks or game-based interactive math activities in such a different, worldwide platform.
\end{abstract}

Keywords: mathematics, gifted, education, student, contest

\section{INTRODUCTION}

In contemporary world, in order to make students discover and internalize the nature of actual math, educational research in mathematics led to the new trends that enable students explore and question mathematics while challenging and motivating them. In this sense, some terms like challenge, competitions, edutainment, mathematical games are more involved in both research area and our lives (Gleason, 2008). For many years, mathematics was perceived by students as unattainable, boring, very abstract and difficult (Ignacio et al., 2006; Kogce et al., 2009). Thus, this led to misperception of mathematics by the students and so, in educational settings, ways that create different mathematical atmosphere in which students are challenged and enjoyed without being dependent on curriculum objectives were looked for. Some informal mathematical experiences like competitions, playing games, and taking part in in clubs may develop math interests of students because they provide an individualized path to the students (Steegh et al., 2019). Among them, in international competitions students who have common goals and perspective in terms of mathematics may have an opportunity to bring together. By using mathematics language, they can get together, make sense of the mathematics, and compete with each other in those competitions. In their nature, children are actually tended to compete with their peers, so integrating the competition in education is a way to help them get accustomed to the real life (Manev et al., 2007; Verhoeff, 1997). In addition to this, as Wahl and Besag (1986) stated in their study, involving in a part of competition initiates the importance of building the achievement on students' own struggle. Moreover, some researchers mentioned about benefits of mathematics competitions in their studies (Michaels \& Forsyth, 1977; Slavin, 1980). To illustrate, Thrasher (2008) unveils that competitions provide challenge both to teachers and students and increase students' interest and curiosity about mathematics. He also highlights that both participation and training process of competitions enable students to make sense of the non-routine mathematical problems which they may not face in their regular classrooms.

Nowadays, qualified mathematics contests assisted the students to be ready for the challenges both in the classroom and daily life, and to be at ease for doing mathematics with their own success, which increase self-confidence of students (Rudnick, 2014). As Kendorov (2006) states, such competitions also create worldwide networks among all participants. This is a good way 
for constructing a culture of mathematics both in schools or in students' interactions with other people across the counties. If not all, such competitions make students think and talk about mathematics different from their regular math lessons restricted to the curriculum objectives. In addition to these general contributions for regular students, many studies (Campbell et al., 2010; Kalman, 2002; Kenderov, 2006; Olszewski-Kubilius \& Lee, 2004; Stockton, 2012) advocate the important role of mathematics competitions in providing opportunities for gifted students. Although gifted children have an inner capacity and potential, transforming these gifts into talent needs special efforts like substantial reinforcement in educational settings (Gagné, 2005). Thus, as Subotnik et al. (1996) state, it is necessary to increase the number of especially gifted students to participate in such organizations because guiding them to study and participate in competitions or Olympiads is a way to develop their talents (Johnson, 2000).

However, it is a reality that organization of a qualified mathematics competition is an actual difficulty (Verhoeff, 1997) and it is important to evaluate these competitions not only from teachers' or educators' perspective but also from students' own perspectives. As stated by many researchers (Danaher, 1994; Fullan, 1991; Weis \& Fine, 1993), it is important to reveal the students' own voices in studies about evaluation of any educational material, in which students are the main characters. Thus, learning the need and efficacy of a process in education from students own in an unstructured way, rather than limiting them to the predetermined and structured options of surveys, is a necessity to obtain more trustworthy data in research (Best et al., 2015). From this point, within the context of this study, it was aimed to examine the contest-related views of the students participating in the Caribou Math Contest which is a worldwide online competition that holds six times throughout one school year. Moreover, due to the fact that meeting up the gifted students with the proper interesting, challenging, beyond curriculum activities that requiring higher level thinking is another issue in gifted education (Ozdemir \& Isiksal, 2021), the present study also intended to evaluate participants' views whether the contest serves the purpose of students needing extra materials/studies in mathematics, like gifted ones.

\section{METHODOLOGY}

\section{Brief Information About Contest}

Caribou Math Contest is a worldwide, international content which intends to show that mathematical puzzles, interactive questions and nonroutine, daily life problems can be fun, exciting, and competing in math contests. It also means to improve students' problem-solving skills by means of challenging math activities and motivate them to make sense of the mathematics. In line with this, in each competition, there are problem-solving questions for students' ability to make application, analysis and synthesis (Figure 1), and, there is a game question (Figure 2), and interactive question (Figure 3), which is prepared by the organization and students can prepare by playing on the website before the contest. In addition, in some contests, there is a history of mathematics (Figure 4) question about which students can reach relevant readings on the contests' web page. After the completion of the contest, the students participating in the contest can voluntarily present their view regarding the contest in a new section where they can make comments. The data analyzed and interpreted through this study comes from these students' views about the contest. 


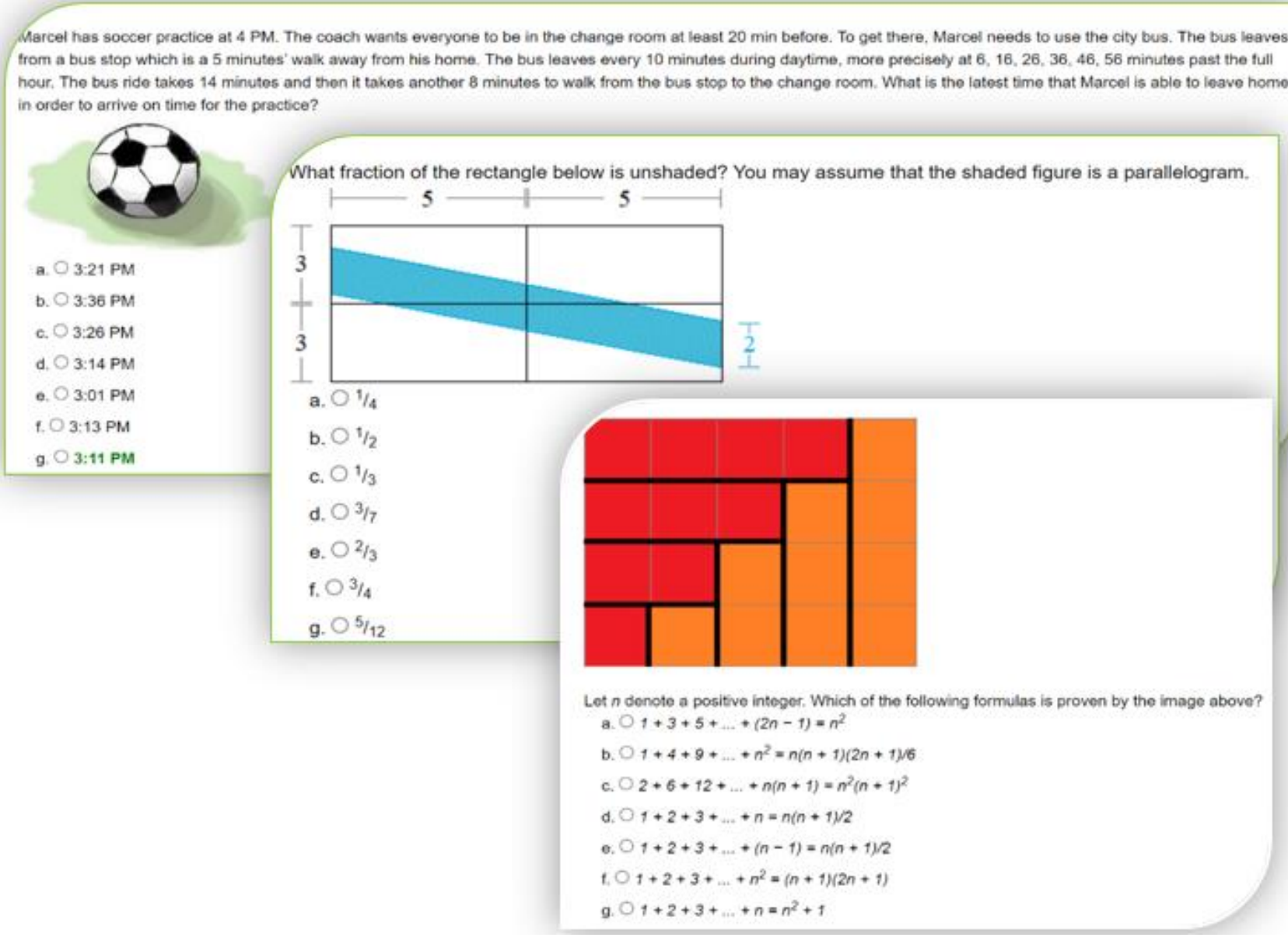

Figure 1. Sample questions from April 2019 contest for 5-6 grade students

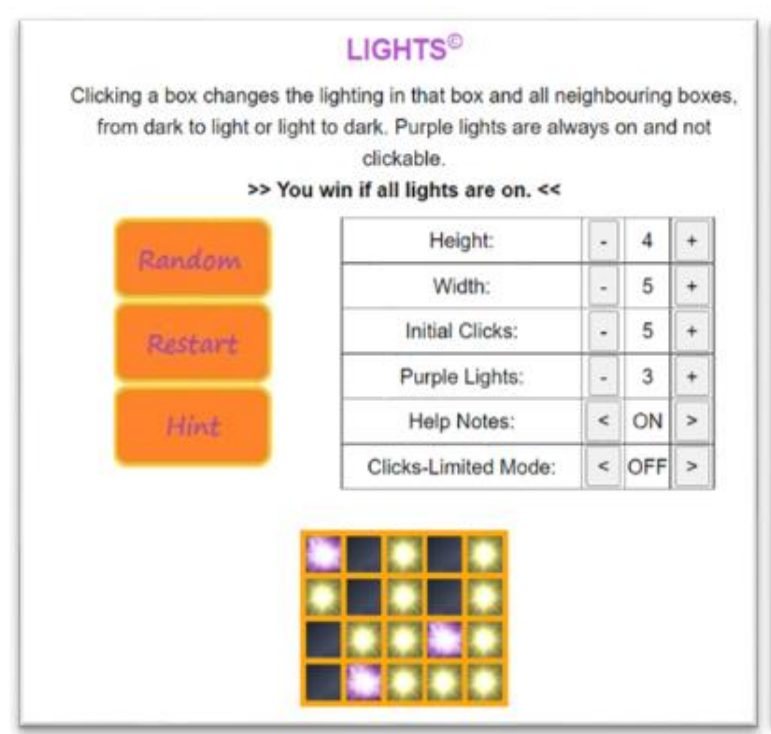

\section{Chomp $^{\oplus}$}

How To Play:

- The game is played weh two players, either you and a friend or you against the computer

- Each pleyer will take tums taking candy from the gind below.

- When a piece of cancy is selected, all the pieces below and to the right of that piece are also removed from the boerd

How To Win:

- The player who takes the last piece of candy from the top left position loses the garne

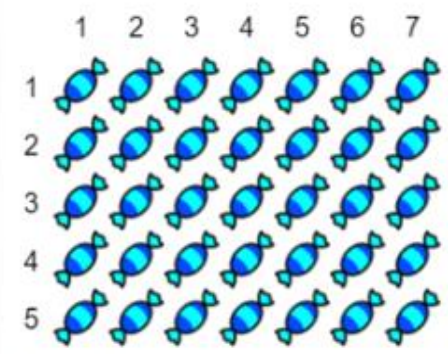

Player 1's Turn

Rostart Computer On Fist Ployer Human Dificulty Easy Undo Comments on

Figure 2. Sample game questions 


\section{Interactive Calcrostic ${ }^{\oplus}$ Puzzle}

- In the following puzzle, numbers are arranged in a $3 \times 3$ square. These numbers satisfy 3 horizontal and 3 vertical relations

- Each letter represents a digit (one of $0,1,2, \ldots, 9)$. Equal letters represent equal digits, different letters represent different digits.

- The problem is to find the value of each letter. Enter these values in the boxes below. When a relation is satisfied, its line will turn green.

- To revert back to the original letter, enter a space in the box.

- Try as often as you like (but beware of the remaining test time!) to get all lines to turn green.

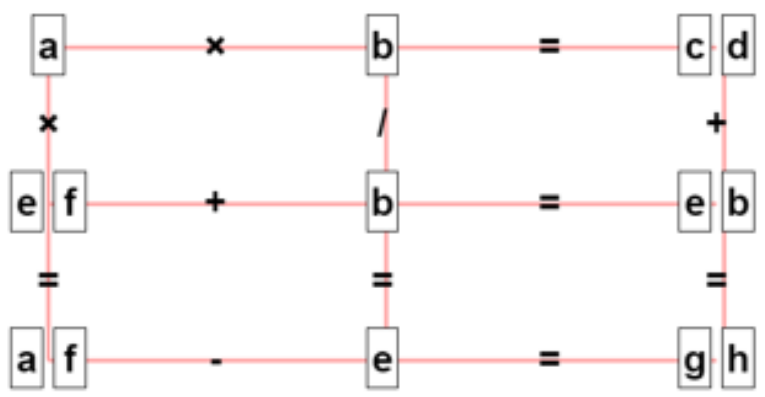

Figure 3. Sample interactive calcrostic puzzle question

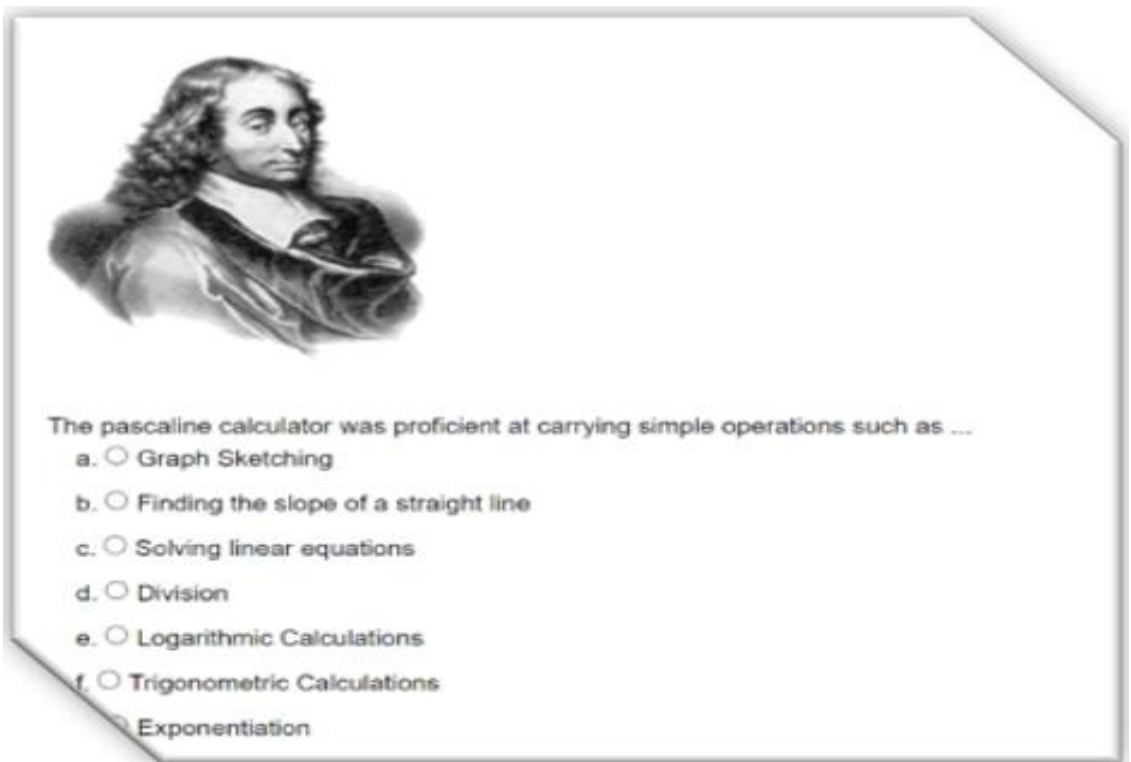

Figure 4. Sample history question from the contest

\section{Participants}

In this study, students' views about Caribou Contests carried out in October, November, and January of 2018-2019 educational terms were analyzed so as to explore their views. In these contests, across 28 different countries, 32124 students participated in October contest, 28427 students participated in November contest while 28795 students participated in January contests. Among those students, as the sample of this study, 224 students from October contest, 187 students from November contest and 186 students from January contest presented their comments upon completion of their test, which provided instant feedback about their views on the contest. Within the scope of this research, the contest data that existed after the competition was taken. Although the information about the gender and age of the students is not available in this competition database, it is known that the students who express their opinions are in the $3^{\text {rd }}-12^{\text {th }}$ grade range.

\section{Data Analysis}

By means of QDA Miner Lite program, the students' views as in the form of qualitative data was analyzed firstly. In this qualitative data analysis process, which allows interpretation of the data in a systematic way (Strauss, 1987), the steps of Miles and Huberman (1994) was followed, and descriptive coding was used to explore the students' views about contest. During this process, memos were used so as to keep the focus and meaning assigned to the codes and they were continuously checked (Creswell, 2007). Moreover, irrelevant data like students' comments having no concern with the contest were removed from the data. After all relevant data was coded, similar codes were clustered and grouped into categories which lead to valid interpretation of the data as the students' views. In this process, constant comparative approach (Strauss \& Corbin, 1990) was preferred and instead of using pre-set codes, these categories emerged from the codes of the data itself. At the end of the process, categories were tested, and it was seen that all relevant units of data were placed into categories, which means saturation of the categories (Lincoln \& Guba, 1985). Furthermore, so as to ensure the reliability of the analysis, intercoder agreement, which was found acceptable (Strauss \& Corbin, 1990) as $80 \%$, was calculated among coders. 
Thus, the qualitative data obtained from students' comments lead to three categories: students' favorable views, students' unfavorable views about contest and students' suggestions for the upcoming contests. In addition to this qualitative analysis of the data, codes and categories obtained from this process were also analyzed quantitatively. That is, frequency of the codes and categories as well as percentages were calculated to get a holistic interpretation of the data. The codes assigned to the categories with percentages based on frequency of the codes were provided in Table 1.

Table 1. Percentages of codes and themes emerged from the analysis

\begin{tabular}{lcc}
\hline Categories/Themes & Codes & Percentages \\
\hline Favourable views about the contest & Liking/Thankful & 18.0 \\
& Hard but good & 17.5 \\
& Fun & 12.5 \\
& 8.5 \\
& Awesome & 4.0 \\
& Educational & 3.0 \\
\hline Unfavourable views about the contest & Games & 10.1 \\
& High level & 2.3 \\
& Not liking & 2.0 \\
Suggestions for upcoming contests & History & \\
& Game & 1.3 \\
\hline
\end{tabular}

\section{FINDINGS}

The main aim of the study was examining students' views about Caribou Mathematics Contest. Based on this main aim, the findings of the study were obtained as students' favorable and unfavorable views about the contests as well as their suggestions for the upcoming contests. As seen in the Table 1, findings of the study reflected that $63.5 \%$ of the students' views about contests conducted in October, November, and January are favorable while $15.7 \%$ of them are unfavorable. That is, it can be said in a general manner, when compared to negative remarks, most of the students shared their positive remarks about contests because the ones indicating favorable comments were considerably more than unfavorable ones. In addition to the students' views about favorable and unfavorable, $20.8 \%$ of the students preferred to share their suggestions as their views about the contest.

When we investigate favorable views category, it can be seen that students expressing their favorable views mostly mentioned about liking the contest (18.0\%) while most of the other views concentrated on their satisfaction with the challenge of the questions (17.5\%). Besides, students found the contests as fun, awesome and educational as well as indicating their positive expressions about the enjoyment of the games, which are the indicator of favorable views about the contest conducted for these students. Before probing the difficulty issue of the contest, it should be highlighted that an important amount of the students commented as fun (12.5\%) and awesome (8.5\%) for the contest and they usually used the affirmative words like great, fun, amazing, interesting, enjoyment, and so on. Here are some examples from their own statements:

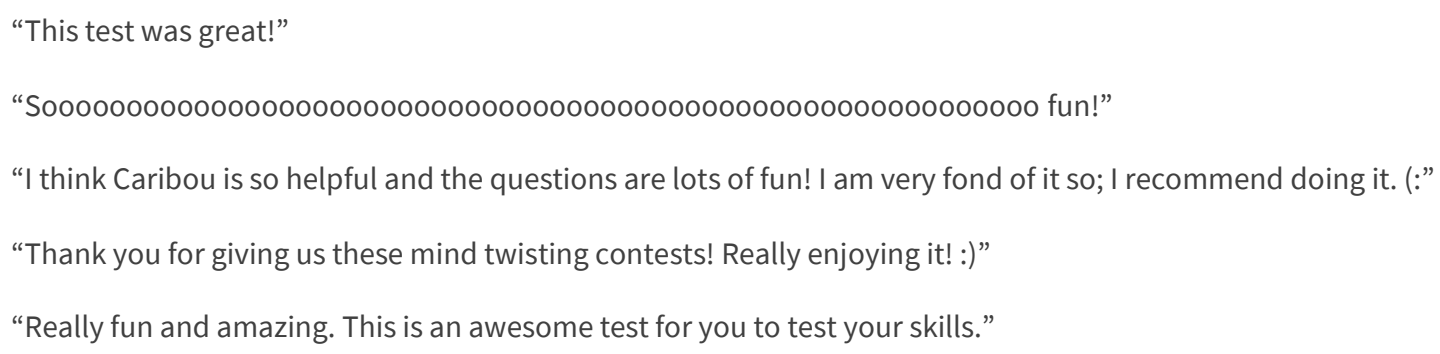

On the other hand, as findings reflect, small number of participants reflected their negative views about contest. When their data analyzed, it was seen that $10.1 \%$ of the students, which is the highest percentage in unfavorable view category, stated their negative views due to the difficulty level of the problems. Conversely, $18.0 \%$ of the students in favorable views category had stated their positive views due to the high level of the contest; that is, they stated their views as finding the contest hard but fun. As an illustration for this, here are students' own words indicating this satisfaction:

"I loved it, keep up the good work and keep making it more and more challenging!"

"Hey this is a very hard test but helps a lot for my brain, enjoyed."

"I love challenging caribou contests, good high-level questions. I look forward to it every day."

Thus, although some of these students complained about hardness or high level of the test like stating "It was too hard", it could be seen that the most of students were especially pleased to face with challenge. In other words, except from suggestions (20.8\%), among students expressing the opinions as favorable or unfavorable had 79.2 of percentage, $17.5 \%$ of them stated their 
satisfaction with the challenge of the contest frankly. At that point, because challenge is one of the core dimensions that should be provided in the tasks of gifted students (Chamberlin, 2002; Diezmann \& Watters, 2001; Gavin et al., 2007; Hammer, 2002; Karaduman, 2010; Leikin, 2010; Ozdemir \& Isiksal, 2021; Sriraman, 2003), the findings of the study could be interpreted in a way that the contest can meet the needs of students who require extra challenging tasks. As seen from their own statements, some of the students were so contented with the hardness of the contest, even looking forward to other contests. For instance,

“The test was challenging and fun: D can't wait for the next one!"

"This was a very fun as well as challenging test. P.S.-Looking forward to doing the next challenging test!"

Other issue stated mostly by students as unfavorable side of the test is that the students (2.0\%) were complaining about one of the history questions asked in January contest. That is, in fact, students didn't present unfavorable view for the contest itself, they were object to the existence of a history question in a math contest.

"The only thing that got me a bit upset was that you added a history question. Caribou math is called Caribou MATH for a reason, right? For this I just want to do math and nothing more or less."

"The question about Rene Descartes is unfair because it is not something that can be found out logically or mathematically but is a sheer memorization question that is not the core idea of this test, so it cannot reasonably be expected to be taken for points."

Although some of the students stated adverse views about history question, it should be noted in here that history of mathematics is something that should be provided to mathematically gifted students (Aydemir \& Cakıroglu, 2013; Özdemir, 2018; Ozdemir \& Isiksal, 2021). That is, although having some unfavorable comments, the contest may be helpful for gifted students to inform them history of mathematics, which may be interesting for gifted students who are curious about the past, depth and background of the concepts (Yevdokimov, 2007). Here are some examples from the word of the students satisfied with this math history questions:

"Thanks for the question about math history."

"I can access the history of mathematics information that I could not learn in school, I read this on website, and you asked the question in the competition. That was good."

Furthermore, a considerable amount of comments was regarding the educational dimension of the contest in the favorable views' category. That is, findings reflected that students have positive views about the contest because they think that it helped them to learn something new or difficult to learn. Here is one of the students' comment about educational side of the contest:

"I love Caribou Math! It teaches me a lot of new things that I did not know before. If you are about to start the contest and you are nervous, then do not be because you will learn a lot of new things!"

Similarly, some students mentioned that the contest helped them for the development of their math skills. For instance,

"Cool math contest. I love it improving my math skills!"

"Caribou is a great way 2 improve your math skills."

Similarly, some of the students stated their views concerning the contribution of the contest to their thinking process as,

"That was hard. Thanks though, it really made me think."

"Hello Caribou team, firstly I'd like to thank about this great exam. It really uses your mind and forces you to think deliberately."

"Very challenging. I truly loved the awesome method of making your brain think!"

"This was amazing! The questions really pushed my thinking limits."

As these data reflected, some of the students were satisfied with the improvement that the contest provided them. Based on the idea that gifted students need higher level thinking to improve their critical thinking (Chamberlin \& Chamberlin, 2010; Freiman, 2006; Karaduman, 2010; Leikin, 2010; McComas, 2011; Sriraman, 2003), by means of this contest which held 6 times in a year, questions needing higher level thinking may fulfill the gifted students' needs of higher order thinking.

Additionally, games of the contest were the other dimension of the findings that was obtained both in the categories of favorable and unfavorable views. That is, $1.3 \%$ of the students expressed their negative comments about the game used in the contest. For instance,

"I didn't like the light game because I couldn't achieve it." 
In other respects, $3 \%$ of the students presented their favorable views about the games in the contest. Furthermore, it was seen in the suggestions category that $2 \%$ of the students mentioned about games as their suggestions for existence of more games in upcoming contests. For example,

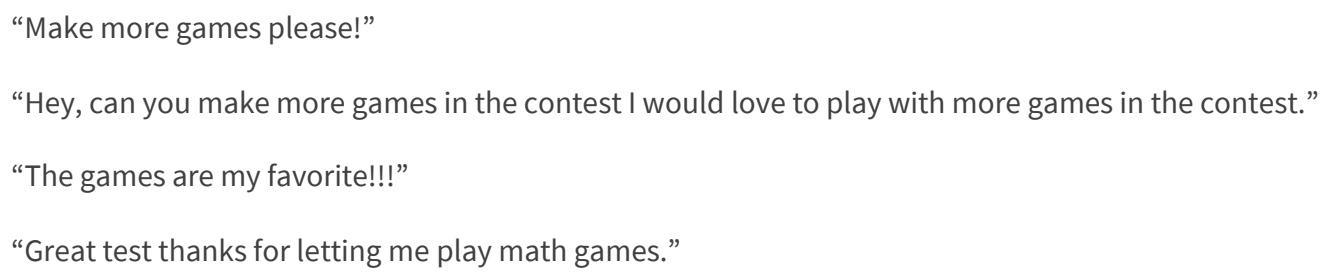

What is more, when other suggestions made by the participants of the contest analyzed, it was deduced that some of the students proposed to make the contest easier or giving more time to complete them while some of the students recommended to make the contest easier at the same time. Students also suggested additional rules or properties for the games. For example, they proposed to have bonus questions, hints at some parts, warnings about timing, a mini challenge every week for fun, questions like what stands for " $E$ " in $E=m c^{2}$.

In general, the students participating in the contest have mostly favorable views about such an international mathematics contest, as can be seen in Figure 5. The fact that the contest only run by its English, French, Chinese, and Irish form, some of the students in other countries like in Germany, Turkey, Russia, South Korea, Thailand, and Dominican Republic made the contest in their foreign language. Furthermore, despite curriculum differences among these countries as well as language difficulty, the participants mostly shared their positive comments upon the completion of the contest and many of them thanked for involving in such an online, worldwide math platform.

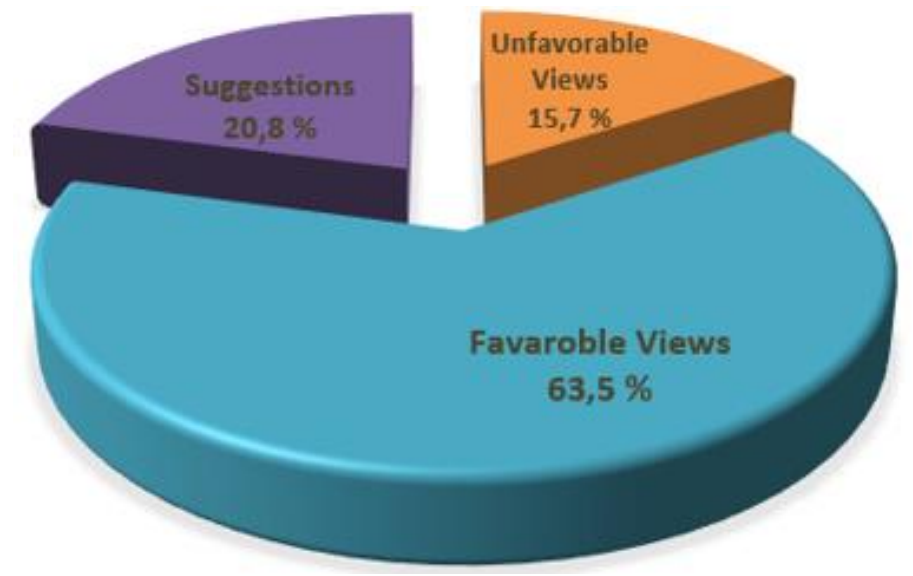

Figure 5. Students' views about Caribou contest

\section{DISCUSSION AND CONCLUSION}

To discuss general findings, let us handle the issue from different perspectives. It is a reality that in mathematics education, providing different experiences to students is important. So as to do this, to show the real face of mathematics that is related to daily life, challenging and joyful, an amusing competition that motivates students is an opportunity for mathematics education. Furthermore, in their teaching, teachers look for some qualified problems for their students in classrooms. However, they may not face with these qualified problems or may not find enough time for constructing or searching for such extra materials. On the contrary, teachers' beliefs or perspectives may limit their way of presenting mathematics itself and its materials to their students, which make it difficult. Hence, this situation may prevent teachers from providing their students with a quality understanding, perspective, materials and education in mathematics (Sztajn, 2003). At that point, contests can serve this purpose; they can combine these problems and materials which were constructed by the experts in a systematics way and provides these excellent resources to the teaches (McLoughlin, 2003). In addition to this, National Council of Teachers of Mathematics (NCTM, 1989, 1998) states that "mathematics can be thought of as a language that must be meaningful if students are to communicate mathematically and apply mathematics productively". Thus, the teachers should make an effort to integrate mathematical conservations in their teaching or provide opportunities that enable them to use and understand the importance of mathematical languages. Herein, international contests come into play again and they may help to bring the students from all over the world together and provide them to use the same mathematical language, which creates a unifying and integrating effect (NCTM, 1988; Wakefield, 2000).

On the other hand, when we think about competition types, in mathematics Olympiads or strict mathematics competitions, the content may be full off drill questions or difficult mathematical concepts that are beyond students' grade level. Even, for some of these contests, the students have to learn other basic concepts beyond their grade level. However, in competitions in which students are asked to solve nonroutine problems by using their mathematical thinking, challenged in accordance with their grade level/age learn how to struggle by using their mathematical thinking or critical thinking skills. The reason why majority of the 
students in this study stated favorable views might be the existence of these kind of questions. By means of the problems, games or interactive puzzles, the students could make sense of the problems through their existence knowledge. Furthermore, in mathematics Olympiads, most of the questions are somewhat far away from their existence knowledge and harder, which may lead to anxiety for the students. However, there are 3, 4, and 5 points questions in this contest and the students might have easily solved 3 points and even 4 points questions. Thus, students who are not gifted and have not excessive mathematical talent could find opportunity to use their mathematical knowledge in these kinds of questions and even challenged themselves in their own level and get enjoyed from the games. Thus, this may have provided them edutainment and led to the positive conclusions on their feelings or views about the contest.

It is a fact that the students can find many easy and similar tasks in many resources both online and offline because most of the instruction and materials are developed for the regular students (Chamberlin \& Chamberlin, 2010) and the education materials are mostly full of test based, similar exercises or problems which are unique to those countries' assessment system and prerequisites. Therefore, it is very difficult to find tasks that are challenging, joyful and different, real life mathematical problems proper to their grade level. Besides, as these results indicate, although few students perceived the contest as too challenging and difficult, the contest mostly served the students who request and desire challenge in their tasks. Moreover, it can be concluded that the contest can attain the goals of students searching for extra services in mathematics by providing them challenging problem-solving tasks or game based interactive math activities in such a different, worldwide platform. Furthermore, as seen from the findings, many of the students mentioned that they liked the test, they thanked and found it as fun or awesome. Thus, this contest may prevent the myth that mathematics contests or mathematics itself are generally boring, confusing and even lead to anxiety because it is not easy for a math contest to take this amount favorable comments; like "Math is amazing by means of Caribou test".

Some of the studies in literature do not reflect the same idea about the benefits of competitions in educational environments. For instance, while Michaels and Forsyth (1977) advocate cooperative environments, Sharan et al. (1980) advocate competitive environments in education. However, as Trueman (2001) stated, both cooperative and competitive environments should be involved in students' lives. In line with this, Thrasher (2008) advocates the competitions and sumps up the benefits of mathematical competitions. Even, the results of this study coincide with his ideas in terms of providing challenge for students, increase students' active involvement in process and their curiosity, enthusiasm and exploration of nonroutine problems. In addition to these, he also mentions about the role of the competitions in recognizing the students who are good at math and problem solving. Besides, in addition to this recognition, some researchers (Kalman, 2002; Riley \& Karnes, 1998; Thrasher, 2008) also supports math competitions or contests for enabling the development of gifted potentials in educational environments.

That is, these results may indicate that such contests may provide opportunities for gifted students who need to struggle, enjoy, solve puzzles, and attain beyond curriculum objectives in their mathematical tasks (Johnson, 2000) and who necessitate special tasks to stimulate and improve their thinking skills (Reger, 2006). In the comprehensive study conducted by Ozdemir and Isiksal (2021), the content characteristics required for the mathematically gifted students' differentiated tasks was found as challenging, interesting and requiring higher-level thinking. Thus, it might be said that the students' reasons about their favorable views coincides with these characteristics needed by the mathematically gifted students. Thus, this study could address a way to show that by giving voice to students' own comments, such contests may meet the needs of the students, especially gifted ones. On the other hand, since the data was drawn from the database of a contest, the information about details of participants' descriptive information was not exist in the contest's database and the data was limited to the participant students who voluntarily and anonymously indicated their views. Since the results this study are limited to its participants, it is recommended to reveal the opinions of students and even teachers about similar competitions/contests/olympiads held all over the world. In addition, the views of this competition from different years can be examined and comparative results can be revealed. As another further study, students' views, and total contest points may be compared to see whether the ones who stated favorable opinions successful or unsuccessful in the test. To sum, as the findings of the study reflected, mathematics competitions can be seen as an important tool for mathematics education and especially for the education of gifted students in mathematics. For this reason, it is recommended that teachers and teacher candidates have a high awareness in this regard and have knowledge about such national and international competitions they can lead and support their students, especially talented in mathematics.

Author contributions: All authors have sufficiently contributed to the study, and agreed with the results and conclusions.

Funding: No funding source is reported for this study.

Declaration of interest: No conflict of interest is declared by authors.

\section{REFERENCES}

Aydemir, D., \& Cakıroglu, E. (2013). Üstün yetenekli ilköğretim öğrencilerinin matematik derslerine ilişkin algıları [Perceptions of gifted primary school students about mathematics lessons]. Proceedings of the $12^{\text {th }}$ MATDER Semposium (pp. 266-268), Ankara, Turkey.

Best, K., Jones-Katz, L., Smolarek, B., Stolzenburg, M., \& Williamson, D. (2015). Listening to our students: An exploratory practice study of ESL writing students' views of feedback. Tesol Journal, 6(2), 332-357. https://doi.org/10.1002/tesj.152

Campbell, J. R., Cho, S., \& Feng, A. X. (2010). Academic competition. A bridge to more opportunities for the talented. Roeper Review, 33(1), 5-7. https://doi.org/10.1080/02783193.2011.530201

Chamberlin, M. T., \& Chamberlin, S. A. (2010). Enhancing preservice teacher development: Field experiences with gifted students. Journal for the Education of the Gifted, 33(3), 381-416. https://doi:10.1177/016235321003300305 
Chamberlin, S. A. (2002). Analysis of interest during and after model eliciting activities: A comparison of gifted and general population students [PhD Thesis, Purdue University].

Creswell, J. W. (2007). Qualitative inquiry and research design: Choosing among five traditions (2nd ed.). SAGE.

Danaher, M. (1994). Summary report of a study investigating issues of concern to the effective teaching of listening skills to beginning students of Japanese as a Foreign Language (JFL). Queensland Researcher, 10, 17-25.

Diezmann, C. M., \& Watters, J. (2001). The collaboration of mathematically gifted students on challenging tasks. Journal for the Education of the Gifted, 25, 7-31. https://doi.org/10.1177/016235320102500102

Freiman, V. (2006). Problems to discover and to boost mathematical talent in early grades: A challenging situations approach. The Mathematics Enthusiast, 3(1), 51-75. https://scholarworks.umt.edu/tme/vol3/iss1/3

Fullan, M. G., \& Hargreaves, A. (1991). What's worth fighting for? Working together for your school. The Regional Laboratory for Educational Improvement of the Northeast \& Islands, Andover. https://files.eric.ed.gov/fulltext/ED342128.pdf

Gagné, F. 2005. From gifts to talents: The DMGT as a developmental model. In R. J. Sternberg \& J. Davidson (Eds.), Conceptions of giftedness (2nd ed.). Cambridge University Press. https://doi.org/10.1017/CB09780511610455.008

Gavin, M. K., Casa, T. M., Adelson, J. L., Carroll, S. R., Sheffield, L. J., \& Spinelli, A. M. (2007). Project M3: Mentoring mathematical minds-A research-based curriculum for talented elementary students. Journal of Advanced Academics, 18(1), 566-585. https://doi.org/0.4219/jaa-2007-552

Hammer, E. J. (2002). Changes in math attitudes of mathematically gifted students taught in regular classroom settings from fourth to seventh grade. Dissertation Abstracts International, 63, 1708. https://www.elibrary. ru/item. asp?id=5287650

Ignacio, N. G., Nieto, L. J. B., \& Barona, E. G., (2006). The affective domain in mathematics learning. International Electronic Journal of Mathematics Education 1(1), 16-32. https://doi.org/10.29333/iejme/169 https://www.iejme.com/article/the-affectivedomain-in-mathematics-learning

Kalman, R. (2002). Challenging gifted students: The Math Olympiads. Understanding Our Gifted, 14(4), $13-14$. https://eric.ed.gov/?id=EJ653804

Karaduman, G. B. (2010). Üstün yetenekli öğrenciler için uygulanan farklılaştırılmış matematik eğitim programları [Differentiated mathematics education programs for gifted students]. Hasan Ali Yücel Eğitim Fakültesi Dergisi [Journal of Hasan Ali Yücel Faculty of Education], 13(1), 1-12.

Kenderov, P. S. (2006, August). Competitions and mathematics education. Proceedings of the International Congress of Mathematicians (pp. 1583-1598), Madrid, Spain. https://doi.org/10.4171/022-3/76

Kogce, D., Yıldız, C., Aydın, M., \& Altındağ, R. (2009). Examining elementary school students' attitudes towards mathematics in terms of some variables. Procedia-Social and Behavioral Sciences, 1(1), 291-295. https://doi.org/10.1016/j.sbspro.2009.01.053

Leikin, R. (2010). Teaching the mathematically gifted. Gifted Education International, 27(2), 161-175. https://doi.org/10.1177/026142941002700206

Lincoln, Y. S., \& Guba, E. G. (1985). Establishing trustworthiness. Naturalistic Inquiry, 289, 331.

Manev, K., Kelevedjiev, E., \& Kapralov, S. (2007). Programming contests for school students in Bulgaria. Olympiads in Informatics, 1, 112-123. https://ioinformatics.org/journal/INFOL010.pdf

McComas, K. K. (2011). Mathematically gifted students' experiences of challenge with cognitively guided instruction [Doctoral dissertation, University of Arkansas].

McLoughlin, J. G. (2003). The role of mathematics contests. Canadian Mathematics Education Study Group, 111-115.

Michaels, L. A., \& Forsyth, R. A. (1977). Construction and validation of an instrument measuring certain attitudes toward mathematics. Educational and Psychological Measurement, 37(4), 1043-1049. https://doi.org/10.1177/001316447703700429

Miles, M. B., \& Huberman, A. M. (1994). Qualitative data analysis: An expande sourcebook (2nd Ed.). SAGE.

National Council of Teachers of Mathematics (1998). NCTM's statem ent of belief. https://www.nctm.org/

Olszewski-Kubilius, P., \& Lee, S. (2004). The role of participation in in-school and outside-of-school activities in the talent development of gifted students. Journal of Secondary Gifted Education, 15(3), 107-123. https://doi.org/10.4219/jsge-2004-454

Ozdemir, D., \& Isiksal Bostan, M. (2021). A design based study: Characteristics of differentiated tasks for mathematically gifted students. European Journal of Science and Mathematics Education, 9(3), 125-144.

Reger, B. H. (2006). How does participation in inquiry-based activities influence gifted students' higher order thinking? [PhD Thesis, Purdue University].

Riley, T. L., \& Karnes, F. A. (1998). Mathematics + competitions = A winning formula! Gifted Child Today Magazine, 21(4), $42-48$. https://doi.org/0.1177/107621759802100413

Rudnick, J. (2014). Success by numbers: Canada math competitions help prepare students for challenges ahead. Gazette-Ontario Association for Mathematics, 53(1), 22.

Slavin, R. E. (1980). Cooperative learning. Review of Educational Research, 50(2), 315-342. https://doi.org/10.3102/00346543050002315

Sriraman, B. (2003). Mathematical giftedness, problem solving, and the ability to formulate generalizations: The problem-solving experiences of four gifted students. Prufrock Journal, 14(3), 151-165. https://doi.org/10.4219/jsge-2003-425 
Steegh, A. M., Höffler, T. N., Keller, M. M., \& Parchmann, I. (2019). Gender differences in mathematics and science competitions: A systematic review. Journal of Research in Science Teaching, 56(10), 1431-1460. https://doi.org/10.1002/tea.21580

Stockton, J. C. (2012). Mathematical competitions in Hungary: Promoting a tradition of excellence \& creativity. The Mathematics Enthusiast, 9(1), 37-58.

Strauss, A. L. (1987). Qualitative analysis for social scientists. Cambridge University Press. https://doi.org/10.1017/CBO9780511557842

Strauss, A., \& Corbin, J. (1990). Basics of qualitative research: Grounded theory procedures and techniques. SAGE.

Subotnik, R. F., Miserandino, A. D., \& Olszewski-Kubilius, P. (1996). Implications of the Olympiad studies for the development of mathematical talent in schools. International Journal of Educational Research, 25(6), 563-573. https://doi.org/10.1016/S08830355(97)86733-X

Sztajn, P. (2003). Adapting reform ideas in different mathematics classrooms: Beliefs beyond mathematics. Journal of Mathematics Teacher Education, 6(1), 53-75. https://doi.org/10.1023/A:1022171531285

Thrasher, T. N. (2008). The benefits of mathematics competitions. Alabama Journal of Mathematics, 33, $59-63$. http://ajmonline.org/2008/12.pdf

Verhoeff, T. (1997). The role of competitions in education. Future World: Educating for the 21st Century, 1-10.

Wahl, M., \& Besag, F. (1986). Gender, attribution, and math performance [Paper presentation]. 67th annual meeting of the American Educational Research Association, San Francisco, CA, USA.

Wakefield, D. V. (2000). Math as a second language. The Educational Forum, 64(3), $272-279$. https://doi.org/10.1080/00131720008984764

Weis, L., \& Fine, M. (Eds.) (1993). Beyond silenced voices: Class, race, and gender in United States schools. State University of New York Press.

Yevdokimov, O. (2007). Using the history of mathematics for mentoring gifted students: Notes for teachers. Proceedings of the 21st Biennial Conference of the Australian Association of Mathematics Teachers (pp. 267-275), Hobart, Tasmania. 